\title{
Catatan Penelitian \\ Sifat Fisik Edible Film yang Terbuat dari Tepung Pati Umbi Garut dan Minyak Sawit
}

Physical Properties of Edible Films Made from Arrowroot Starch Flour and Palm Oil

Amalina Noor Shabrina*, Setya Budi Muhammad Abduh, Antonius Hintono, Yoga Pratama

Program Studi Teknologi Pangan, Fakultas Peternakan dan Pertanian, Universitas Diponegoro, Semarang

*Korespondensi dengan penulis (amalinanoors@gmail.com)

Artikel ini dikirim pada tanggal 15 Januari 2017 dan dinyatakan diterima tanggal 18 Juni 2017. Artikel ini juga dipublikasi secara online melalui www.jatp.ift.or.id. Hak cipta dilindungi undang-undang. Dilarang diperbanyak untuk tujuan komersial.

Diproduksi oleh Indonesian Food Technologists® @2017

\section{Abstrak}

Penelitian ini bertujuan untuk mengetahui sifat fisik edible film dari tepung pati umbi garut dan minyak sawit dengan perbedaan konsentrasi antar keduanya, serta mengetahui konsentrasi yang tepat antara beberapa perlakuan yang menghasilkan edible film terbaik. Penelitian ini dirancang secara acak lengkap (RAL) dengan dua faktor. Faktor I adalah konsentrasi tepung pati umbi garut $(3 \%, 4 \%$, dan $5 \% \mathrm{~b} / \mathrm{v})$ dan faktor II adalah penambahan konsentrasi minyak sawit $(0 \%, 0,3 \%$, dan $0,6 \% \mathrm{v} / \mathrm{v})$. Setiap perlakuan dilakukan sebanyak 3 kali ulangan dengan parameter yang diujikan yaitu berupa ketebalan, water vapor transmission rate, tensile strength, dan persentase pemanjangan. Nilai water vapor transmission rate terbaik yaitu sebesar $10,691 \mathrm{~g} / \mathrm{m}^{2} / \mathrm{jam}$ dengan formula konsentrasi tepung pati umbi garut $5 \%(\mathrm{~b} / \mathrm{v})$ dan konsentrasi minyak sawit $0,6 \%(\mathrm{v} / \mathrm{v})$. Pada nilai water vapor transmission rate ini, nilai ketebalan yang diperoleh yaitu $0,1134 \mathrm{~mm}$, tensile strength $2,8 \mathrm{~N} / \mathrm{mm}^{2}$ dan presentase pemanjangan $43 \%$. Dalam menentukan nilai, tepung pati umbi garut dan minyak berinteraksi $(P<0,05)$ pada nilai ketebalan, water vapor transmission rate, dan persentase pemanjangan namun tidak berinteraksi $(P>0,05)$ dalam menentukan nilai tensile strength.

Kata kunci: sifat fisik, edible film, umbi garut, minyak sawit

\begin{abstract}
The purpose of this research is to determine the physical properties of edible film from arrowroot starch flour and palm oil with difference concentration between both of them, and also to investigate the right concentration among some treatment which have best result. This research used Completely Randomized (CRD) is arranged with two factors. The first factor was the concentration of arrowroot stratch flour (3\%, $4 \%$, and $5 \% \mathrm{~b} / \mathrm{v})$ and the second was the concentration of palm oil $(0 \%, 0,3 \%$, and 0,6\% v/v). Each treatments for 3 replication, with paramaters measured were thickness, water vapor transmission rate, tensile strength and elongation. The best result of water vapor transmission rate that is $10,691 \mathrm{~g} / \mathrm{mm}^{2} /$ hour, with formula of the concentration of arrowroot starch flour is $5 \%$ and then concentration of palm oil is $0,6 \%$. In this value of water transmission rate, the value of thickness is $0,1134 \mathrm{~mm}$, tensile strength $2,8 \mathrm{~N} / \mathrm{mm}^{2}$ and elongation $43 \%$. The result showed the interaction between concentration of arrowroot starch flour and palm oil against the thickness, water vapor transmission rate, and elongation $(P<0,05)$. But, there is no interaction with tensile strength $(P>0,05)$.
\end{abstract}

Keywords: physical properties, edible film, arrowroot, palm oil

\section{Pendahuluan}

Bahan pengemas pangan yang banyak digunakan adalah plastik yang terbuat dari polimer hasil ekstraksi dari minyak bumi. Misalnya jenis PP, PVC, PET dll. Plastik semacam ini memiliki sifat barrier terhadap oksigen, karbondioksida maupun dengan uap air (Ardiansyah, 2011). Namun plastik memiliki kelemahan, yaitu merupakan pengemas yang bersifat non biodegradable sehingga limbah dari plastik ini dapat mencemari lingkungan. Kondisi ini mendorong perlunya bahan pengemas pangan yang bersifat ramah lingkungan tetapi juga memiliki keunggulan yang khas. Edible film merupakan salah satu solusi yang bisa digunakan sebagai bahan pengemas yang ramah lingkungan sehingga dapat mengurangi pencemaran lingkungan. Edible film merupakan lapisan tipis yang memiliki fungsi sebagai bahan pengemas atau pelapis pada makanan yang sekaligus dapat dimakan bersama dengan produk yang dikemas (Guilbert et al., 1996).

Edible film dapat dibuat dari berbagai polisakarida, protein, lipid dan kombinasi ketiganya (Robertson, 2013). Pati merupakan jenis polisakarida yang potensial untuk pembuatan edible film dengan karakteristik fisik yang mirip plastik, tidak berwarna, tidak berbau, dan tidak berasa. Bahan pembuat edible film dengan berbahan dasar pati sudah banyak dilakukan antara lain menggunakan pati aren, jagung, ubi jalar, talas (Pangesti et al., 2014). Umbi garut berpotensi sebagai bahan pembuat edible film karena memiliki kadar pati cukup tinggi, yang tidak kalah dengan umbi-umbi yang lain seperti ketela pohon, ketela rambat, kentang dan jenis umbi-umbian yang lain.

Penggunaan minyak sawit pada penelitian ini bertujuan untuk memperbaiki karakteristik dari edible film. Edible film yang terbuat dari pati memiliki kelemahan yaitu resistensinya terhadap uap air rendah karena pati bersifat hidrofilik dimana dapat mempengaruhi stabilitas dan sifat mekanisnya (Garcia et al., 2011). Maka dari itu, penggunaan minyak sawit sebagai bahan tambahan pada pembuatan edible film yaitu untuk menurunkan permeabilitas terhadap uap air dan dapat meningkatkan sifat fisik edible film lainnya. 


\section{Metode Penelitian}

Penelitian ini telah dilaksanakan di Laboratorium Rekayasa Pangan, Jurusan Pertanian, Fakultas Peternakan dan Pertanian, Universitas Diponegoro, Semarang. Rancangan percobaan dalam penelitian ini menggunakan Rancangan Acak Lengkap (RAL) dengan dua faktor. Faktor pertama adalah penambahan tepung pati umbi garut $\mathrm{P}_{1}=3 \%, \mathrm{P}_{2}=4 \%$, dan $\mathrm{P}_{3}=5 \%(\mathrm{~b} / \mathrm{v})$ dan faktor ke dua adalah penambahan minyak sawit $\mathrm{M}_{1}=0 \%, \mathrm{M}_{2}=0,3 \%$ dan $\mathrm{M}_{3}$ $=0,6 \%(\mathrm{v} / \mathrm{v})$ dengan 3 kali pengulangan sehingga terdapat 27 unit percobaan. Parameter yang diamati adalah ketebalan, water vapor transmission rate, tensile strength, dan persentase pemanjangan.

\section{Pembuatan Tepung Pati Umbi Garut}

Pembuatan tepung pati umbi garut dilakukan sesuai dengan prosedur yang telah dilakuakn oleh Badan Litbang Pertanian (2011), dengan beberapa modifikasi. Langkah pertama yaitu melakukan penyortiran, pembersihan, pengupasan dan pencucian umbi garut dari kotoran serta sisiknya. Selanjutnya penimbangan umbi garut sebanyak $1 \mathrm{~kg}$ lalu diblender dan ditambahkan aquadest sebanyak $1 \mathrm{~L}$ (1:1). Kemudian disaring dengan kain saring, pada hasil saringan akan terbentuk endapan, endapan tesebut dipisahkan dari air kemudian ditaruh pada loyang. Hasil endapan tersebut dikeringkan menggunakan cabinet dryer suhu $50^{\circ} \mathrm{C}$ selama 24 jam. Selanjutnya setelah dikeringkan, endapan tersebut dihaluskan dengan mesin penghalus yaitu Beaterbar miller Maksindo FCTZ300 selama 2 menit. Jika sudah halus maka tepung pati umbi garut diayak menggunakan mesh ukuran 80 hingga menghasilkan tepung pati umbi garut yang betekstur halus.

\section{Pembuatan Edible Film}

Pembuatan edible film bersesuaian dengan prosedur yang telah dilakukan oleh Warkoyo et al. (2014) dengan sedikit modifikasi. Langkah pertama yaitu dimulai dengan menyiapkan bahan-bahan. Bahan-bahan yang digunakan yaitu tepung pati umbi garut $(3 \%, 4 \%$, dan $5 \% \mathrm{~b} / \mathrm{v})$ dalam aquadest $100 \mathrm{ml}$, penambahan minyak sawit $(0 \%, 3 \%$, dan $6 \% \mathrm{v} / \mathrm{v}$ larutan tepung pati umbi garut), plasticizer gliserol $(0,4 \% \mathrm{v} / \mathrm{b}$ tepung pati umbi garut), dan kuning telur $(20 \% \mathrm{v} / \mathrm{v}$ minyak). Kemudian pencampuran bahan-bahan, Ialu di homogenizer dengan kecepatan 8000 rpm selama 5 menit. Selanjutnya pemanasan dan pengadukan menggunakan magnetic stirrer dengan suhu $250^{\circ} \mathrm{C}$ kecepatan $6 \mathrm{rpm}$ hingga larutan mencapai suhu $85^{\circ} \mathrm{C}$. Lalu mempertahankan suhu selama 5 menit agar sifat gelatinisasinya terjaga. Selanjutnya menuangkan larutan edible film sebanyak $55 \mathrm{ml}$ pada teflon yang berdiameter $15 \mathrm{~cm}$. Lalu pengeringan menggunakan cabinet dryer suhu $35^{\circ} \mathrm{C}$ selama 24 jam. Kemudian melepas edible film dari teflon secara perlahan. Sebelum menguji mutu obyektif, edible film diuji tampilannya yaitu edible film yang dihasilkan harus rata menutupi permukaan teflon, komponen minyak dan pati dapat tercampur dengan rata yaitu tidak menimbulkan spot minyak. Edible film yang sudah lolos uji tampilannya kemudian diuji mutu obyektifnya.
Pengukuran Ketebalan

Ketebalan edible film diukur dengan metode yang telah dilakukan pada penelitian Ningsih (2015), dengan cara mengukur kelima tempat permukaan edible film menggunakan mikrometer skrup (model MDC-25M, Mitutoyo, MFG, Japan) dengan ketelitian $0,001 \mathrm{~mm}$. Edible film yang telah diukur pada lima tempat yang berbeda, lalu hasilnya dirata-ratakan dan dinyatakan dengan satuan $\mathrm{mm}$.

\section{Pengukuran Water Vapor Transmission Rate}

Pengujian water vapor transmission rate dimulai dari memotong edible film berbentuk lingkaran yang disesuaikan dengan mulut cawan yang akan digunakan. Cawan gelas diberi aquadest sebanyak $\pm 50 \mathrm{ml}$, lalu menutup cawan menggunakan edible film tersebut menggunakan bantuan wax dan karet sebagai perekat. Menimbang berat awalnya dan menyimpan pada $\mathrm{RH}$ chamber terkontrol (kelembaban $\pm 55 \%$ ). Setiap setengah jam (selama 6 jam) cawan dikeluarkan untuk ditimbang. Nilai water vapor transmission rate dinyatakan dalam $\mathrm{g} / \mathrm{m}^{2} / \mathrm{jam}$ dan dihitung menggunakan persamaan menurut Sukkunta (2005):

$$
\operatorname{WVTR}=(\mathrm{G} / \mathrm{t}) / \mathrm{A}
$$

Keterangan:

$\mathrm{G} / \mathrm{t} \quad$ : Selisih pertambahan berat air yang diserap oleh edible film (g/jam)

A : Luas Area Edible film $\left(\mathrm{m}^{2}\right)$

\section{Pengukuran Tensile Strength}

Pengujian tensile strength dilakukan dengan memotong sampel edible film dengan ukuran $15 \mathrm{~cm} \times$ $1 \mathrm{~cm}$ kemudian edible film dijepit $\pm 5 \mathrm{~cm}$ dikedua sisi panjangnya lalu di uji dengan menggunakan alat texture analyzer (TA Plus - Lloyd Instruments). Tensile strength dihitung dengan persamaan:

Tensile Strength $=\mathrm{F}$ maksimum $/ \mathrm{A}$

Keterangan:

F maksimum : Gaya maksimum (N)

A : Luas Area Edible film $\left(\mathrm{mm}^{2}\right)$

\section{Pengukuran Persentase Pemanjangan}

Pengujian persentase pemanjangan dilakukan dengan memotong sampel edible film dengan ukuran $15 \mathrm{~cm} \times 1 \mathrm{~cm}$ kemudian edible film dijepit $\pm 5 \mathrm{~cm}$ dikedua sisi panjangnya lalu di uji dengan menggunakan alat texture analyzer (TA Plus - Lloyd Instruments). Persentase pemanjangan dihitung dengan persamaan :

Keterangan :

$$
E: 100 \% \times\left(d_{\text {after }}-d_{\text {before }}\right) / d_{\text {after }}
$$

d : jarak antara penjempit pemegang sampel menjelang (before) atau sesudah (after) sampel ditarik hingga putus.

\section{Analisis Data}

Data hasil pengukuran ketebalan, water vapor transmission rate, tensile strength, dan persentase pemanjangan dianalisis dengan uji pengaruh menggunakan Anova (Analysis Of Variance) pada taraf 
signifikansi $5 \%$ dan dilanjutkan dengan Duncan (Duncan's Multi Range Test) untuk mengetahui kombinasi perlakuan yang terdapat pengaruh. Uji Duncan digunakan untuk mengetahui perlakuan tepung pati umbi garut dan minyak sawit.

\section{Hasil dan Pembahasan}

\section{Ketebalan}

Hasil analisis ragam menunjukkan adanya pengaruh interaksi antara tepung pati umbi garut dan minyak sawit terhadap ketebalan edible film $(P<0,05)$. Peningkatan konsentrasi tepung pati umbi garut mampu meningkatkan ketebalan. Pada ketebalan yang meningkat ini, konsentrasi minyak sawit juga relatif lebih tinggi. Nilai ketebalan tertinggi yaitu pada $\mathrm{P}_{3} \mathrm{M}_{3}$ $(0,1134 \mathrm{~mm})$ diperoleh dari formula dengan konsentrasi tepung pati garut sebesar $5 \%(\mathrm{~b} / \mathrm{v})$ dan konsentrasi minyak sawit sebesar $0,6 \%(\mathrm{v} / \mathrm{v})$. Nilai ketebalan terendah $\mathrm{P}_{1} \mathrm{M}_{1}(0,0629 \mathrm{~mm})$ diperoleh dari formula dengan konsentrasi tepung pati garut sebesar $3 \%(b / v)$ dan konsentrasi minyak sawit sebesar $0 \%(\mathrm{v} / \mathrm{v})$.

Hal tersebut terjadi karena konsentrasi pati dan minyak sawit yang semakin besar, mampu meningkatkan total padatan edible film sehingga film yang dihasilkan semakin tebal. Ketebalan edible film ditentukan oleh konsentrasi pati yang digunakan. Secara visual, semakin tinggi konsentrasi pati pada suspensi semakin tinggi viskositasnya. Viskositas suspensi edible film setelah pemanasan semacam ini, dapat dijadikan penanda ketebalan edible selain plat pencetaknya (Harris, 2001). Pengaruh konsentrasi minyak sawit pada ketebalan edible film sejalan dengan penelitian Rahim et al. (2010) yang menujukkan bahwa peningkatan asam palmitat berpengaruh terhadap ketebalan edible film yang menyebabkan total padatan bertambah.

\section{Water vapor transmission rate}

Hasil analisis ragam menunjukkan adanya pengaruh interaksi antara tepung pati umbi garut dan minyak sawit terhadap water vapor transmission rate edible film $(P<0,05)$. Peningkatan konsentrasi tepung pati umbi garut mampu menurunkan water vapor transmission rate. Pada nilai water vapor transmission rate yang menurun ini, konsentrasi minyak sawit juga relatif tinggi. Nilai water vapor transmission rate tertinggi yaitu pada $\mathrm{P}_{3} \mathrm{M}_{3}\left(15,309 \mathrm{~g} / \mathrm{m}^{2} / \mathrm{jam}\right)$ diperoleh dari formula dengan konsentrasi tepung pati garut sebesar 3\% (b/v) dan konsentrasi minyak sawit sebesar $0 \%(\mathrm{v} / \mathrm{v})$. Nilai water vapor transmission rate terendah $\mathrm{P}_{1} \mathrm{M}_{1} \quad\left(10,691 \mathrm{~g} / \mathrm{mm}^{2} / \mathrm{jam}\right)$ diperoleh dari formula konsentrasi tepung pati garut sebesar $5 \%(\mathrm{~b} / \mathrm{v})$ dan konsentrasi minyak sawit sebesar $0,6 \%(\mathrm{v} / \mathrm{v})$.

Hal tersebut terjadi disebabkan oleh konsentrasi pati yang tinggi sehingga menyebabkan kadar amilosa bertambah yang kemudian dapat meningkatkan jumlah ikatan antar molekul pati membentuk jalinan matrik yang lebih padat sehingga edible film relatif tidak permeable terhadap uap air (Rahim et al., 2010). Transmisi uap air melewati film dapat terjadi karena perbedaan tekanan uap air di kedua sisinya (Liu et al., 2005). Permeabilitas film berkurang lebih jauh sebagai akibat dari penggunaan minyak sawit. Minyak sawit merupakan asam lemak yang bersifat hidrofobik sehingga dapat menahan kecepatan transmisi uap air. Semakin besar konsentrasi minyak sawit yang ditambahkan, semakin kecil nilai water vapor transmission rate yang dihasilkan (Rahim et al., 2010). Edible film yang menggunakan lipid dan hidrokoloid (pati) dapat menguntungkan kedua komponen tersebut dimana lipid dapat meningkatkan ketahanan terhadap penguapan air dan hidrokoloid (pati) dapat memberikan daya tahan karena merupakan barrier yang baik terhadap oksigen, karbondioksida.

\section{Tensile strength}

Hasil analisis ragam menunjukkan tidak adanya pengaruh interaksi antara tepung pati umbi garut dan minyak sawit terhadap nilai tensile strength $(P>0,05)$. Pada Tabel 1. Menunjukkan bahwa tensile strength edible film meningkat dengan semakin meningkatnya konsentrasi tepung pati umbi garut dari konsentrasi $3 \%$, $4 \%$, dan $5 \%(\mathrm{~b} / \mathrm{v})$. Hal tersebut berseuaian dengan pendapat Rahim et al. (2010) dengan penambahan pati yang semakin banyak, matriks yang terbentuk semakin banyak pula, struktur matriks film semakin kokoh sehingga kekuatan yang diberikan untuk menyangga beban dari luar semakin besar.

Sedangkan penambahan konsentrasi minyak sawit menghasilkan nilai tensile strength yang tidak konsisten. Tensile strength film dengan konsentrasi minyak sawit $0,3 \%$ lebih tinggi dibandingkan tensile strength film dengan konsentrasi minyak sawit $0 \%$ dan $0,6 \%$. Nilai tensile strength pada penelitian ini sejalan dengan penelitian Pangesti et al., 2014 yang menggunakan tepung pati talas dan asam palmitat. Nilai tensile strength pada penelitiannya menunjukan bahwa edible film dengan penambahan konsentrasi lipid yang lebih rendah (5\%) menghasilkan nilai tensile strength yang lebih tinggi dibandingkan dengan penambahan lipid yang tinggi (15\% dan $20 \%$ ). Hal tersebut diduga dengan penggunaan lipid yang semakin banyak, memberikan struktur edible film yang lebih rapuh terhadap matrik film sehingga kekuatan untuk menahan kerusakan mekanis semakin rendah. Ikatan yang terbentuk antara gugus non polar minyak sawit dan gugus polar dari air kemungkinan cenderung tidak stabil. Akibatnya tidak terbentuk ikatan kimia yang baik antara minyak dan air, sehingga dapat menurunkan kekuatan tarik film dan menyebabkan film akan mudah patah (Listiyawati, 2015).

\section{Persentase Pemanjangan}

Hasil analisis ragam menunjukkan adanya pengaruh interaksi antara tepung pati umbi garut dan minyak sawit terhadap ketebalan edible film $(P<0,05)$. Peningkatan konsentrasi tepung pati meningkatkan persentase pemanjangan. Pada peningkatan persentase pemanjangan ini, konsentrasi minyak sawit menjadi relatif rendah. Nilai persentase pemanjangan tertinggi yaitu pada $\mathrm{P}_{3} \mathrm{M}_{1}(47 \%)$ diperoleh dari formula dengan konsentrasi tepung pati garut sebesar $5 \%(b / v)$ dan konsentrasi minyak sawit sebesar $0 \%(\mathrm{v} / \mathrm{v})$. Nilai persentase pemanjangan terendah $\mathrm{P}_{2} \mathrm{M}_{3} \quad(30 \%)$ diperoleh dari formula konsentrasi tepung pati garut sebesar $4 \%(b / v)$ dan konsentrasi minyak sawit sebesar $0,6 \%(\mathrm{v} / \mathrm{v})$. Namun $\mathrm{P}_{2} \mathrm{M}_{3} \quad(30 \%)$ tidak berbeda nyata dengan $\mathrm{P}_{1} \mathrm{M}_{2}(31 \%)$. 
Tabel 1. Mutu Edible Film yang Dibuat dari Tepung Pati Umbi Garut dan Minyak Sawit

\begin{tabular}{|c|c|c|c|c|c|c|c|c|c|}
\hline \multirow[t]{2}{*}{ Parameter } & \multicolumn{9}{|c|}{ Perlakuan } \\
\hline & $P_{1} M_{1}$ & $\mathrm{P}_{2} \mathrm{M}_{1}$ & $\mathrm{P}_{3} \mathrm{M}_{1}$ & $P_{1} M_{2}$ & $\mathrm{P}_{2} \mathrm{M}_{2}$ & $\mathrm{P}_{3} \mathrm{M}_{2}$ & $P_{1} M_{3}$ & $\mathrm{P}_{2} \mathrm{M}_{3}$ & $\mathrm{P}_{3} \mathrm{M}_{3}$ \\
\hline Ketebalan (mm) & $0,063^{f}$ & $0,074^{c}$ & $0,088^{\mathrm{e}}$ & $0,068^{b}$ & $0,082^{d}$ & $0,099^{f}$ & $0,072^{b c}$ & $0,087^{e}$ & $0,113^{9}$ \\
\hline WVTR $\left(\mathrm{g} / \mathrm{m}^{2} / \mathrm{jam}\right)$ & $15,31^{\dagger}$ & $13,69^{e}$ & $13,20^{d}$ & $12,56^{\mathrm{cd}}$ & $11,88^{\mathrm{bc}}$ & $11,20^{\mathrm{ab}}$ & $11,71^{b}$ & $10,76^{a}$ & $10,69^{a}$ \\
\hline $\begin{array}{l}\text { Tensile Strength } \\
\left(\mathrm{N} / \mathrm{mm}^{2}\right)\end{array}$ & 1,506 & 1,709 & 2,760 & 1,811 & 2,619 & 3,047 & 1,421 & 1,838 & 2,824 \\
\hline $\begin{array}{l}\text { Persentase. } \\
\text { Pemanjangan (\%) }\end{array}$ & $39^{c}$ & $43^{\text {de }}$ & $47^{f}$ & $31^{a}$ & $37^{\mathrm{b}}$ & $41^{d}$ & $38^{\mathrm{bc}}$ & $30^{\mathrm{a}}$ & $44^{\mathrm{e}}$ \\
\hline
\end{tabular}

* Superskrip yang berbeda pada baris yang sama menunjukkan beda nyata $(P<0,05)$

Keterangan $\quad: P_{1} \quad=$ Tepung Pati Umbi Garut 3\%

$P_{2} \quad=$ Tepung Pati Umbi Garut $4 \%$

$P_{3} \quad=$ Tepung Pati Umbi Garut $5 \%$

$\mathrm{M}_{1} \quad=$ Minyak Sawit $0 \%$

$\mathrm{M}_{2} \quad=$ Minyak Sawit 0,3\%

$\mathrm{M}_{3} \quad=$ Minyak Sawit $0,6 \%$

Berdasarkan dari hasil penelitian ini, dapat dilihat bahwa semakin tinggi konsentrasi tepung umbi garut, persentase pemanjangan edible film semaki besar. Hal tersebut bersesuaian dengan penelitian Kusumawati dan Putri (2013). Penggunaan tepung pati jagung pada penelitiannya mampu meningkatkan persentase pemanjangan film dengan semakin tinggi konsentrasi tepung pati jagung yang digunakan. Hal tersebut disebabkan karena dengan konsentrasi pati yang digunakan lebih banyak maka dapat membentuk jaringan tiga dimensi yang kompak sehingga menghasilkan gel yang kuat. Minyak ternyata juga berperan dalam menentukan nilai persentase pemanjangan. Semakin tinggi kandungan lipid maka semakin rendah nilai persentase pemanjangan edible film yang dihasilkan. Hal tersebut diduga lipid yang ditambahkan menimbulkan globula lemak yang berlebihan dan mengganggu ikatan hydrogen antar molekul penyusun film.

\section{Potensi Aplikasi}

Berdasarkan fitur yang dimilikinya, edible film yang dihasilkan dari penelitian ini berpotensi sebagai pengemas produk dengan sifat elastis mudah dibentuk, kadar air dan kadar lemak yang relatif tinggi. Salah satu produk dengan sifat semacam ini adalah jenang dodol. Nilai ketebalan edible film yang relatif tinggi $(0,1134 \mathrm{~mm})$ dan nilai water vapor transmission rate yang rendah $\left(10,691 \mathrm{~g} / \mathrm{m}^{2} / \mathrm{jam}\right)$ dapat mengurangi transmisi uap air sehingga mencegah jenang dodol dari kondisi lembek atau kering, melindungi dari oksidasi minyak yang ada pada dodol, dan menjaga aroma sehingga dapat memperpanjang umur simpan produk. Jenang dodol memiliki tekstur lunak, dan mudah untuk dibentuk. Dengan nilai tensile strength $2,8 \mathrm{~N} / \mathrm{mm} 2$, film yang dihasilkan sudah memenuhi standar sebagai alat pengemas produk sehingga mampu melindungi produk dari gangguan mekanis dengan baik sekaligus dapat mempertahankan strukturnya dan fungsinya pada saat produk mengalami perlakuan fisik.Standar nilai tensile strength edible film yaitu sekitar 1-10 $\quad \mathrm{N} / \mathrm{mm}^{2}$ (Rachmawati, 2009). Namun hasil tersebut cenderung lebih rendah dari penelitian Harris (2001), nilai tensile strength edible film yang digunakan sebagai pengemas dodol durian pada penelitiannya yaitu sebesar 6.97 $\mathrm{N} / \mathrm{mm}^{2}$.
Berdasarkan nilai persentase pemanjangan yang digunakan sebesar 43\%. Krochta dan Johnston (1997) dalam Suryaningrum et al. (2005) menyebutkan bahwa persentase pemanjangan edible film dikatakan kurang baik jika nilainya kurang dari $10 \%$ dan dikatakan baik jika nilainya lebih dari $50 \%$, mutu edible film sudah memenuhi standar sebagai pengemas produk. Namun hasil tersebut cenderung lebih rendah dari penelitian Harris (2001), yaitu dengan nilai persentase pemanjangan edible film $72,9 \%$ sebagai pengemas dodol durian.

\section{Kesimpulan dan Saran}

Berdasarkan hasil penelitian dapat disimpulkan bahwa pati umbi garut dan minyak sawit berinteraksi pada nilai ketebalan, water vapor transmission rate, dan persentase pemanjangan namun tidak berinteraksi dalam menentukan nilai tensile strength. Nilai water vapor transmission rate terbaik sebesar 10,691 $\mathrm{g} / \mathrm{m}^{2} / \mathrm{jam}$ dihasilkan dari konsentrasi tepung pati umbi garut $5 \%(\mathrm{~b} / \mathrm{v})$ dan konsentrasi minyak sawit 0,6\% (v/v). Pada nilai water vapor transmission rate ini, nilai ketebalan yang diperoleh yaitu $0,1134 \mathrm{~mm}$, tensile strength $2,8 \mathrm{~N} / \mathrm{mm}^{2}$ dan presentase pemanjangan $43 \%$. Salah satu produk yang dapat dikemas menggunakan edible film ini adalah dodol. Untuk menghasilkan edible film dengan sifat yang baik, perlu penentuan konsentrasi minyak sawit yang tepat untuk memperoleh nilai tensile strength dan persentase pemanjangan edible film yang tinggi.

\section{Daftar Pustaka}

Ardiansyah, R. 2011. Pemanfatan Pati Umbi Garut untuk Pembuatan Plastik Biodegradable. Departemen Teknik Kimia. Fakultas Teknik. Universitas Indonesia, Depok. (Skripsi).

Badan Litbang Pertanian. 2011. Proses Pengolahan Tepung Kasava dan Tapioka. Agroinovasi Edisi 4.

Garcia, N. L., L. Ribbon, A. Dufresne, M. Aranguren, and Goyanes. 2011. Effect of Glycerol on the Morphologi of Nanocomposites Made from Thermoplastic Stratch and Stratch Nanocrystals. J. Carbohydrate Polymers. 84 (1): 203-210. 
Guilbert, S., N. Gontard, and L. G. M. Gorris. 1996. Prolongation of The Shelf Life of Perishable Food Using Biodegradable Films and Coatings. Lebensm Wisss. Technol. 29:10-17.

Harris, H. 2001. Kemungkinan Penggunaan Edible Film dari Pati Tapioka Untuk Pengemas Lempuk. Jurnal Ilmu-ilmu Pertanian. 3(2).

Krochta, J. M. and D. M. Johnston. 1997. Edible and Biodegradable Polymer Films: Challenge and Opportunities. J. Food Technology 951(2):6174.

Kusumawati, D. H., dan W. D. R. Putri. 2013. Karakteristik Fisik dan Kimia Edible Film Pati Jagung yang Diinkorporasi dengan Perasan Temu Hitam. Jurnal Pangan dan Agroindustri. 1 (1):90-100.

Liu, Z., and J. H. Han. 2005. Film Forming Characteristics of Starches. Journal Food Science. 70(1):E31-E36.

Listiyawati, O. 2012. Pengaruh Penambahan Plasticizer dan Asam Palmitat Terhadap Karakter Edible Film Karaginan. Program Studi Sains Kimia. Fakultas Matematika dan IImu Pengetahuan Alam. UNS, Surakarta. (Skripsi)

Ningsih, S., H. 2015. Pengaruh Plasticizer Gliserol Terhadap Karakteristik Edible Film Campuran Whey dan Agar. Fakultas Peternakan. Universitas Hasanuddin, Makassar. (Skripsi)

Pangesti, D. A., A. Rahim, dan G. S. Hutomo. 2014. Karakteristik Fisik, Mekanik dan Sensoris Edible
Film dari Pati Talas pada Berbagai Konsentrasi Asam Palmitat. Agrotekbis Universitas Tadulako. 2(6): 604-610.

Rachmawati, A. 2009. Ekstraksi dan Karakterisasi Pektin Cincau Hijau untuk Pembuatan Edible Film. Fakultas Pertanian Universitas Sebelas Maret, Surakarta. (Skripsi)

Rahim, A., N. Alam, Haryadi, dan U. Santoso. 2010. Pengaruh Konsentrasi Pati Aren dan Minyak Sawit Terhadap Sifat Fisik dan Mekanik Edible Film. J. Agroland. 17(1):38-46.

Robertson, L. G. 2013. Food Packaging Principles and Practice. CRC Press. New York.

Sukkunta, S. 2005. Physical and Mechanical Properties of Chitosan-Gelatin Based Film. Department Technology of Environmental Mangement. Faculty of Graduate Studies. Mahidol University. Thailand.

Suryaningrum D. T., J. Basmal, dan Nurochmawati. 2005. Studi Pembuatan Edible Film dari Karaginan. J. Penelitian Perikanan Indonesia. 11(4):1-13.

Warkoyo, B. Rahardjo, D. W. Marseno, dan J. N. W. Karyadi. 2014. Sifat Fisik, Mekanik dan Barrier Edible Film Berbasis Pati Umbi Kimpul yang Diinkorporasi dengan Kalium SorbAt. FTP UGM. 34 (1). 